\title{
Deliberative democracy : from Rational Discourse to Public Debate
}

\author{
Mattias Kettner \\ Universität Witten/Herdezcke \\ kettner@uni-wh.de
}

\begin{abstract}
This paper will discuss the concept of a "deliberative" democracy. Various key authors on deliberative democracy will be highlighted: James Bohman, Amy Gutmann, Jürgen Habermas and John Rawls. The role for political communication of the mass media and of the internet will be outlined.
\end{abstract}

Keywords: Deliberative democracy, democratic legitimacy, public reason, discourse ethics, mass-media, Jürgen Habermas, John Dewey, James Bohman, Amy Gutmann.

Practices of public deliberation play an essential role in recent theorizing about democracy and, in particular, "deliberative" democracy. However, little attention is usually paid to the role of the mass media in such practices of governance. My objective in this paper is to prepare a framework for the normative evaluation, criticism and appraisal of mass-mediated communication specifically in relation to the requirements of deliberative democracy.

\section{Democratically required Forms of Publicity}

Consider the following essentialist argument from the concept of publicity. Publicity, one might say, is the condition of

(1) being known as a permitted topic for conversation, or knowable without special effort, to all members of a community of communication,

(2) where this condition itself is public in the sense of (1). 
Publicity in this sense can be glossed as non-exclusionary thematizability. Any form of democracy (so the argument goes) requires publicity - be it in a minimalist sense of the publicity required for general elections and other voting procedures or be it in the more demanding sense in which we speak of rational opinion formation as a public process, e.g, when citizens deliberate with regard to political public goods. The mass media control the overall flow of public communication. So they provide, shape, channel publicity, engendering it and limiting it at the same time. Hence democracy requires the mass media.

This conclusion is not exactly wrong but it is not exactly right either. Consider: What is really required for democracy are suitable forms of publicity; and nothing intrinsic to mass-mediated communication guarantees that a particular mass media configuration will generate or support rather than destroy or impede such forms. As a matter of fact, any form of political governance needs "suitable" forms of publicity. This holds for dictatorships, for theocraties, and other "well-ordered" (in the sense which John Rawls gave the term) but non-democratic societies. Any form of political governance must involve mass media that are configured in the right way for providing its requisite forms of publicity.

To the extent that alternative ways for generating such forms are insufficient or do not exist at all, mass media are integral to political governance and good political governance depends (in some measure) on whether their overall configuration suits the respective form of political governance.

How should a set of mass media be configured so that they support or at least do not subvert a democratic regime of political governance? This question can be rephrased in the following way: What is it for a configuration of media to be conducive to those forms of publicity that are required in order for some particular mode of democratic governance to flourish? This sense 'required' is a broadly functionalist sense that is available in normative as well as in non-normative theories of democracy.

Within non-normative theories of democracy, different theoretical models of democracy may compete for empirical adequacy or some other laudatory mark of sociological excellence. But we inevitably move from non-normative into normative theories of democracy as soon as a particular theoretically specified form of democratic governance has to be justified as being more recommendable as a form of political governance than other democratic (or non-democratic) forms of political governance.

Normative theories of democracy vindicate particular forms of democratic governance as politically good governance (or politically better than $\mathrm{x}$ ) by elaborating distinctive political rationales whose justificatory potentials can be compared and evaluated. How does media-theory bear on this? The gamut of media theories ranges from the cultural to the engineering sciences and is a variegated field of broadly empirical knowledge about the realities (functions, structures, effects, history, "software", "hardware", etc.) of mass-mediated communication. Assume we subscribe to a particular normative theory of democracy that vindicates some particular form D of democratic governance, e.g., governance by a secular parliamentary representative state system, as in France. This permits us to frame 
media political prescriptions. Consider the following schematic justification for media political proposals:

(1) For such and such reasons $\mathrm{R}$, we ought politically to prefer to govern our affairs in the framework of a political system that accords with $\mathrm{D}$.

(2) Our normative theory of democracy helps us to distinguish between forms of publicity that are in alliance with $\mathrm{D}$ and those which are not.

(3) Given what our best media theory says about media realities, we have reason to think that subversive forms of publicity (as specified in 2) are in fact related to such and such determinate features of the media configuration that we have or could establish if we so wished.

(4) We ought politically to prefer changes in our media system that bring the relevant features of that system closer to changes into the direction of forms of publicity that are in alliance with $\mathrm{D}$ and away from those which are not (as implied by $2 \& 3$ ).

Note that whatever the right features of the media turn out to be, the media ought to have them for no other reasons than for those which already do all the normative work in premise (1): reasons by appeal to which we can justify claims that we make on each other as citizens to the effect that something ought politically to be preferred, or that politically preferring something - having some determinate political preference - is a valid policy for us to try out. Depending on their respective foundational strategy, normative theories of democracy will differ in what they specify should count as good R-reasons in premise (1), since different normative theories of democracy employ different conceptions of the political, of political governance, and of what democratic political governance is good for. Is democracy "best viewed as a device for protecting rights, a device for aggregating mere preferences, a device for distributing power, or a device for identifying political truths?"1

\section{Democratic Legitimacy as rooted in the Consent of the Governed}

Depending on what we hold to be the most important point of democratic political governance, democracy has been defended because it results in wise policies, or in a just society, or in a free society, or that it engenders decisions which promote the public interest or the common good, or that respect individual rights, or promote science and intellectual activity, and so on. "The list is limited only by one's resourcefulness in enumerating the good things of life and the conviction with which one is able to argue that democracy will promote them".

1 Copp, David \& Hampton, Jean \& Roemer, John E. (1993), eds.: The idea of democracy. Cambridge: Univ. Press, p. 18.

2 Jones, Peter (1982): Political Equality and Majority Rule. In J. Arthur (1992) ed., Democracy. Theory and Practice. Belmont, Wadsworth (208-222), p. 209f. For a critical discussion see Cohen, Carl (1971): Democracy. Athens, Univ. of Georgia Press. 
We may add to this rhapsody of outcome-oriented rationales of democratic modes of governance still other normative theories of democracy, namely those that elaborate specifically procedure-oriented rationales. The procedurally most important point of democratic political governance, then, may be glossed as "communicative rationality" of the legislative process, ${ }^{3}$ or alternatively as "faimess" in the sense of treating as equal all citizens' interests that arise out of their membership in the political community, ${ }^{4}$ or as "fair compromise". All normative theories of democracy have in common that each particular conception of good political governance can be rephrased in the language of normative claims to intersubjective bindingness, i.e., in terms such as 'political legitimacy', 'political validity', or 'political acceptability'. The reason is that any notion of democratic governance, be it outcome or process oriented or both, must somehow refer to the consent of the governed, and political legitimacy, validity, or acceptability are systematic elaborations of the democratic core notion of the consent of the governed.

Let 'democratic legitimacy' be shorthand for what normative theories of democracy seek to articulate as a distinctive, namely political, form of normativity. Democratic legitimacy should be associated with democratic political arrangements and should not be reducible to other forms of normativity, e.g. moralities or religious commandments. If a normative theory of democracy claims on strength of some rationale that democratic legitimacy of any particular use of political power, (e.g. formulating and putting into force a certain piece of legislation) ought to rest on good reasons, then it must also claim that such reasons ought to be public reasons. Otherwise, some or all the citizens who stand to be affected by that particular use of political power would have to consent or dissent for no reason at all, or for no reason known to all citizens alike. The consent of the governed would be, for that matter, uninformed, ignorant, blind. Interestingly, the allegation that such blindness is the predominant condition in democracies is a standard topic in cynical or sceptical attacks against too sanguine claims of normative theories of democracy. ${ }^{6}$

Supposedly, the easiest way to render reasons public is by making them known via mass mediated communication. If mass media can in fact be so configured that they can satisfy this condition which is (according to the rationale of the respective normative theory of democracy) a necessary condition for all claims of democratic legitimacy, then they ought politically to be so configured (on strength of the same rationale).

However, with publicity being merely a necessary condition on reasons of democratic legitimacy, we do not have much to go on. Now let us make the condition stronger. Consider: The rational point of giving reasons is their use in

\footnotetext{
3 Habermas, Jürgen: Between Facts and Norms. Cambridge, MIT Press 1996.

4 Beitz, Charles (1989): Political Equality: An Essay in Democratic Theory. Princeton, Univ. Press.

5 Singer, Peter (1973): Democracy and Disobedience. Oxford, Univ. Press.

6 See the meanwhile classic controversy between Walter Lippmann (Lippmann, Walter (1925): The Phantom Public. New York, Harcourt) and John Dewey (The Public and its Problems. J.A. Bodyston (1988) ed., The Later Works 1925-1953. Carbondale, Southern Illinois Univ. Press, pp. 235-372). For a more recent trenchant scepticism see Herman, Edward S. \& Chomsky, Noam (1988): Manufacturing Consent. The Political Economy of the Mass Media. New York, Pantheon.
} 
available practices of deliberation and argumentation. Reason-giving and practices of argumentative discourse are rational complements. The publicity of reasons thus has its rational complement in the availability of public deliberation and argumentation.

Of course, not all normative theories of democracy exploit this complementarity (which in turn has to be justified in a theory of rationality). Call those that do, the "advocats of deliberative democracy". Advocats of deliberative democracy maintain that democratic legitimacy must rest on, i.e. ought politically to rest on, no other reasons than reasons that can be made good by public uses of public reasons. ${ }^{7}$

If my aim were to criticize existing theoretical models of deliberative democracy I would criticize them mainly on four counts:

(1) Media ignorance. Although some of the authors of such models realize, however dimly, that mass-mediated communication plays a crucial role for the constitution of 'public reason', they invariably undertheorize the relation between empirical media theory and normative theory of democracy.

(2) Illusionary idealizations: Many models of deliberative democracy involve idealizations that founder on the facts of deep value pluralism and subcommunal fragmentation that are endemic in the political and non-political culture of modernity in advanced capitalist societies today. For instance, Rawls contends that "there are many nonpublic reasons and but one public reason". ${ }^{8}$ In my view, this is a unitarian idealization that renders Rawls' liberalism unrealistic. ${ }^{9}$

(3) Insufficient sensitivity to globalization: The consequences of globaliziation processes on democratic modes of governance remain to be fully accommodated in normative theories of democracy, especially theories of deliberative democracy. ${ }^{10}$

(4) Avoidance of a moral point of view: Often "the domain" of the political is set over against "the moral domain" without due recognition of the fact that political argument has a moral edge to it.

The first and third points are momentous but cannot be elaborated within the confines of this paper. Let me address the fourth point now before I take up the second. Consider the following scenario. You conceive of democracy as a set of institutions that would engender outcomes more in the perceived interest of a majority of society. This gives you a (relative to your conception) good public reason for claiming in debate with me or other German citizens that our public service broadcasting ought politically to be dismantled in favour of commercial

7 The term 'public reason' (cf. Rawls, John: Political Liberalism. New York, Columbia Univ. Press

1993, pp. 212-254) has become common parlance, though interpretations both of public use and of public reasons vary considerably. Compare, for instance, David Gauthier Gauthier ("Public Reason", Social Philosophy and Policy, vol.12 no.1 (1995) pp. 19-42), Gerald Postema ("Public Practical Reason: An Archeology", Social Philosophy and Policy, vol.12 no.1 (1995) pp. 43-86), James Bohman (Public Deliberation. Pluralism, Complexity, and Democracy. Cambridge, MIT Press 1996).

8 John Rawls: Political Liberalism. N.Y., Columbia University Press 1993, p. 220.

9 That Rawls takes "cultural pluralism" only insufficiently into account is forcefully criticized by John Gray (Liberalisms. London, Routledge 1989, cf. ch. $9 \& 10$ ) as well as by James Bohman (Public Deliberation. Pluralism, Complexity, and Democracy. Cambridge, MIT Press 1996, pp. 71-106) who extends his criticism to Habermas' conception of public reason.

10 But see John B. Thompson: The Media and Modernity. Stanford, Univ. Press 1995. 
broadcasting, since a majority of German citizens actually perceive the latter to be more in their interest than the former. I conceive democracy as a set of institutions "which treat all individuals as autonomous agents capable of forming reasoned judgements through the assimilation of information and different points of view, and which institutionalizes a variety of mechanisms to incorporate individual judgements into collective decision-making processes [so that] the legitimacy of a decision stems from the fact that the decision is the outcome of a process of generalized deliberation". ${ }^{11}$ This gives me a (relative to my conception) good public reason for claiming the opposite, since only the former media configuration is legally held up to the task of nourishing public deliberation by fostering a balanced diversity of public reasons. This institutional responsibility is enshrined in article 5 of the German constitution which specifies the responsibility of the public broadcasting system.

When should (your) reasons pertaining to the importance of people's getting what they actually want defeat (my) reasons pertaining to the importance of people's deliberating about what they want? Suppose we do not find sufficient common ground in our different conceptions of democratic legitimacy for deciding our controversy. Yet it is important for both of us which reasons eventually will win out. After all, the legitimacy of a political decision eventually places us under an obligation to comply with it and sanctions state authority to enforce such compliance. This is no small deal. The momentous consequentiality of legitimacy stems from its alliance with coercive power. This is why political deliberation inevitably has a moral edge.

In our controversy, we will soon be driven (in order, for instance, to find a fair compromise) to explore very abstract normative assumptions of our respective conceptions, whence we sail into the waters of a moral discussion. Of course, nothing in this shift from scrutinizing political normativity to scrutinizing moral normativity guarantees us that we will achieve a determinate consensus. But discourse ethics provides at least the morally required parameters for a space of critical reasoning in which we would be free enough to find out. In the next paragraph I turn to the second point on my list of four critical points to consider.

\section{Deliberative Democracy: From Discourse to Public Dialogue}

What is deliberative democracy all about? Gutmann and Thompson give a succinct normative answer along the following lines: "The essential idea is that all institutions of government have a responsibility for deliberation. Institutions should be arranged so as to provide opportunities and incentives for officials and citizens to engage in moral reasoning. Institutions should also be transparent in the sense that their actual purposes should coincide with their publicly acknowledge purposes. (...) The practice of deliberation should not be confined to the institutions of government. Unless citizens have the experience of reasoning together in other institutions in which they spend more of their time they are not likely to develop either the interest

11 John B. Thompson: The Media and Modernity. Stanford, Univ. Press 1995, p. 255. 
or the skill that would enable them to deliberate effectively in politics. That is why it is so important that the processes of decision making that citizens encounter at work and at leisure should seek to cultivate the virtues of deliberation. The discussion that takes place in these settings not only is a rehearsal for political action, but also is itself a part of citizenship in deliberative democracy. Deliberative democracy does not demand that all social institutions primarily serve its ends, but its success does depend on the support of the whole range of intermediary institutions - those that act on citizens (such as the media, health care organizations, professional sports), those in which they act (interest groups, private clubs, trade unions, professional associations), as well as those in which they work (corporations, small businesses, government agencies, military services). In an effort to make democracy more deliberative, the single most important institution outside government is the educational system". "Deliberative democracy is more idealistic than other conceptions because it demands more than democratic politics normally delivers. It is more realistic because it expects less than moral agreement would promise. While acknowledging that we are destined to disagree, deliberative democracy also affirms that we are capable of deciding our common destiny on mutually acceptable terms." 12

It is evident that the deliberation of deliberative democracies cannot be confined to specialized publics (e.g., parliaments) and particular confines of discourse (e.g., constitutional review). Consequently, deliberation in deliberative democracies will have to be practiced in highly diverse settings where people with wildly differing value orientations come together.

Suppose we have strong political and moral arguments that establish that deliberative democracy ought politically and morally to be preferred over various other forms of governance. Then all legitimating reasons for doing politically significant things (e.g., law-making) ought to be such that they can be made good by public uses of public reasons. However, this condition is still too formal. It does not capture that citizens, due to the fact of pervasive value heterogeneity, may differ in their perceptions of the political relevance of any public use of any public reason. The only sensible move for a normative theory of democracy is to embrace this fact, not to deny it. This is hard since it means cutting back on any claim to privileged interpretative authority and acknowledging that "political significance" really is a social construct - an essentially contested one - emerging from the interpretative efforts of all citizens who are actually engaging in such efforts. I propose the following realistic concept of a res publica reason:

For any public use of any public reason $\mathrm{R}$, if a determinate subset $\mathrm{S}$ of citizens share a determinate interpretation of R's political significance because qua members of $S$ they recognize some concern as their common concern, then $\mathrm{R}$ is a res publica reason relative to $S$.

Obviously, $\mathrm{R}$ can be a merely public reason relative to one subset $\mathrm{S} 1$ and fail to be a res publica reason for $S 1$ and at the same time be a res publica reason relative to another subset of citizens, S2. For any action A that is intended to have differential political consequences, $\mathrm{A}$ is legitimate for the subset of citizens who can recognize

12 Amy Gutmann \& Denis Thompson: Democracy and Disagreemant. Cambridge: Harvard University Press 1996, pp. 358, 361. 
in $A$, on the basis of appropriate public uses of relevant and undefeated res publica reasons $\mathrm{R}$, their "res publica", i.e. their common-wealth or common well-being. Deliberation is political, I would like to say, if it aims at scrutinizing, extending or limiting, promoting or withdrawing the recognition of reasons as res publica reasons.

How would communicative public space have to be configured in order to support rather than stifle this kind of deliberation?

It is tempting (at least for some advocates of deliberative democracy) to respond that communicative public space should be configured as a rational discourse. However, a Habermasian concept of fully fledged discourse, though it has great theoretical merits in other respects, cannot embrace drastically differing value orientations that are normal when citizens meet in real public deliberation over some politically controversial issue. ${ }^{13}$

Bohman, after extensively arguing this point, concludes that "what is required in cases of deep conflict is a genuinely moral compromise in which plural public reason is exercised in the process of creating a framework for such an ongoing public consensus, now a minimal one that demands only the willingness to continue to cooperate." 14 Note that "willingness to continue to cooperate" in the face of irreconcilable dissensus is a far weaker and for that matter far more realistic constraint on public deliberation than are the highly demanding rational presuppositions of an argumentative discourse in the Apel-Habermasian sense of that term.

In the remainder of this paragraph I will supplement Bohman's suggestion with John Dewey's interesting concept of a political public. Deweyan political publics emerge as self-organizing responses to external effects of internal activities within a community of interaction and communication: "Indirect, extensive, enduring and serious consequences of conjoint and interacting behavior call a public into existence having a common interest in controlling these consequences." ${ }^{15}$

How so? Dewey distinguishes private and public forms of association. For the members, the consequences of their conduct in private associations are "direct" consequences. But the activities of such groups often have consequences for persons who are not within the group: "indirect" consequences. Sometimes these are perceived as momentous. A Deweyan public comes into existence as soon as some members of a body politic perceive themselves as "indirectly and seriously affected for good or for evil"16 by activities of their co-associates and become interested in bringing those activities and their important indirect consequences under some kind of collectively binding arrangement. One and the same person will belong to

13 For a critical discussion of the general discourse principle that Habermas has introduced in his work on the democratic state (Jürgen Habermas: Between Facts and Norms. Cambridge: MIT-Press 1996) see Matthias Kettner: "The Disappearance of Discourse Ethics in Habermas' 'Faktizität und Geltung'”, in: Rene von Schomberg \& Kenneth Baynes (eds.), Discourse and Democracy. Essays on Habermas's Between Facts and Norms. Albany, N.Y.: SUNY Press 2002, pp. 201-218.

14 James Bohman: Public Deliberation. Pluralism, Complexity, and Democracy. Cambridge, MIT Press 1996, p. 84.

15 John Dewey: "The Public and its Problems". J.A. Bodyston (1988) ed., The Later Works

1925-1953. Carbondale, Southem Illinois Univ. Press, p. 314.

16 Ibid. p. 257. 
different publics, depending on the different ways she is subjected to adverse effects from various sources. The historical contingency in significance-perceptions of practical problems is a correlate of the vicissitudes of political publics. Some publics will be large, some small; some will be limited by geography, others not. No two publics will have precisely the same membership and any given public will have members from other publics. For instance, the subset of citizens that are suffering from the ecological recklessness displayed by Shell in the Brent Spar affair is not identical with the subset of citizens that are threatened by gasoline price increases. There is overlap.

For Dewey, "the" public is always already a public of publics. It is a protean patchwork of more or less determinate multifarious publics in co-evolution, not a single homogeneous "sphere". For any public among publics the primary problem beyond how to achieve enough self-integration - is how to achieve appropriate recognition as a determinate social actor amongst a host of heterogeneous other social actors. Both the finding and identifying itself as a public and the achieving of "such recognition of itself as will give it weight in the selection of official representatives and in the definition of their responsibilities and rights" ${ }^{17}$ can be facilitated or impeded, depending on the production of suitable forms of publicity which in turn depends on the communicative profile of an existing configuration of mass media. Inasmuch as mass-mediated communication is necessary for shared perceptions of indirect, extensive, enduring and serious consequences of conjoint and interacting behavior to occur, the media make political publics; and they make political publics visible inasmuch as mass-mediated communication is necessary for publics to be able to take notice of each other as publics with a potential for becoming social actors.

With the help of their reliably conventionalized aesthetic strategies of imaging, narrating, and highlighting, of condensing and diffusing, centering and decentering, surprizing and repeating, of irritating and reassuring, etc., the mass media manage to populate our imagination, thought, and conversation with variegated social actors, for instance, the state administration, nongovernmental organizations, the legal system, the science system, the churches, the political parties, associations of civil society, and so on. Their "visibility" as social actors which the mass media ought politically to bestow on publics can yield sufficient intelligibility to permit extant or emerging publics to situate themselves in, and to shape intelligent responses to, the ongoing interactions of publics.

The capacity of mass media for generating such intelligibility works satisfactorily, I would maintain, except under extremely adverse societal conditions (e.g., state-centralist models of media organisation, total media illiteracy in substantial segments of a citizenry, total de-professionalization of journalists, etc.). Realistically, normative deliberative democrats will not and need not expect more of the media. 


\section{Conclusion}

Let us draw a conclusion. It is plausible to formulate the general aspirational standard for the "proper" media configuration in a deliberatively democratic society in the following way: Mass media should support rather than subvert the role of Dewean publics as political deliberators.

Political deliberation traces the difference of the political by establishing and checking the recognition of reasons as res publica reasons; and it tracks within the extant body politic the bounds of mutually sharing such recognition (or its withdrawal) across variegated publics of publics. The publics are the bearers of political deliberation, not the media. Media configurations, however, can be judged according to what they do or fail to do and yet could do under given conditions for any and every discernable element of political deliberation that has a significant bearing on the overall rational qualities of such deliberation.

Instead of asking what "ideal" media can do for democracy, pragmatists of deliberative democracy see more value in diagnosing the media realities that we have or that we are likely to see evolve, in order to ask what our diagnosis implies with regard to the flourishing of political deliberation that we cherish. 